\title{
ANALISIS PERBANDINGAN METODOLOGI CUSTOMER SATISFACTION INDEX DALAM RANGKA PENINGKATKAN PELAYANAN KESEHATAN DI INDONESIA
}

\author{
M N Lisan Sediawan \\ Sediawan1003@gmail.com \\ Prodi Kebidanan \\ STIKES Widyagama Husada
}

\begin{abstract}
Customer Satisfaction Index (CSI) is an economic indicator that measures the satisfaction of consumers across nation. This paper discusses the measurement model from an economic point of psychology is positioned as a variable customer loyalty. We will also discuss some studies which include : market segmentation, product positioning, competitiveness, consumer perception, customer satisfaction, and quality of service. To determine the position of the CSI Indonesia compared to other countries CSI inventors and other users it is necessary comparisons and scientific study.. This article discuss 7 methodologies on Consumer Satisfaction Index (CSI) developed by used in respective countries, e.g. Sweden Customer Satisfaction Barometer (SCSB), American Customer Satisfaction Index (ACSI), European Customer Satisfaction Index (ECSI), National Customer Satisfaction Index (NCSI), Japanese Customer Satisfaction Index (JCSI), Customer Satisfaction Index of Singapura (CSISG) and Indonesian Customer Satisfaction Index (ICSC). This study aims to be reference for the development of CSI in Indonesia, particularly in the healthcare, in order to improve the consumer / patient satisfaction.
\end{abstract}

Keywords: Customer, Perception, Quality, Satisfaction, Customer Satisfaction Index, 


\begin{abstract}
ABSTRAK
Indeks Kepuasan Konsumen (Customer Satisfaction Index) adalah metode pengukuran kepuasan pelanggan secara nasional sebagai barometer kepuasan pelanggan dari berbagai sektor ekonomi di suatu negara Tulisan ini membahas model pengukuran tersebut dari sudut pandang ekonomi psikologi yang memposisikan customer loyalty sebagai variabel. Kita juga akan membahas beberapa kajian yang meliputi: Segmentasi pasar, Produk positioning, Daya saing, Persepsi konsumen, Kepuasan konsumen, dan Kualitas layanan. Untuk mengetahui posisi CSI Indonesia dibandingkan dengan negara penemu dan pemakai CSI lain maka perlu perbandingan dan kajian ilmiah. Tulisan ini membandingkan secara metodologis beberapa CSI yang dipergunakan oleh Swedia (SCSB), Amerika (ACSI), Eropa (ECSI),Korea Selatan (NCSI), Jepang (JCSI) Singapura (CSISG) dan Indonesia (ICSI). Kajian ini diharapkan dapat dijadikan sebagai bahan bagi pengembangan CSI di Indonesia khususnya dalam sektor kesehatan, dalam rangka meningkatkan kepuasan konsumen/pasien.
\end{abstract}

Kata kunci: Konsumen, Persepsi, Kualitas dan Indeks Kepuasan Konsumen.

\section{PENDAHULUAN}

Memahami pelanggan akan menuntun penyedia jasa pada tindakan kebijakan yang tepat dan efisien, yaitu dengan memfokuskan bidikan dengan lebih terarah, karena masingmasing segmen pelanggan mempunyai loyalitas, kebiasaan, minat dan lingkungan yang berbeda. Untuk mengetahui keinginan dan kebutuhan pelanggan, maka aspek yang mempengaruhi pelanggan secara individu (persepsi, cara memperoleh informasi, sikap, demografi, kepribadian dan gaya hidup) serta aspek lingkungan (budaya, kelas sosial, kelompok rujukan, proses komunikasi, keluarga) perlu dianalisis (Schiffman \& Leslie, 2000). Analisis keinginan dan kebutuhan pelanggan dapat dilihat pada Gambar 1 yaitu Model Perilaku Pelanggan (Schiffman \& Leslie, 2000).

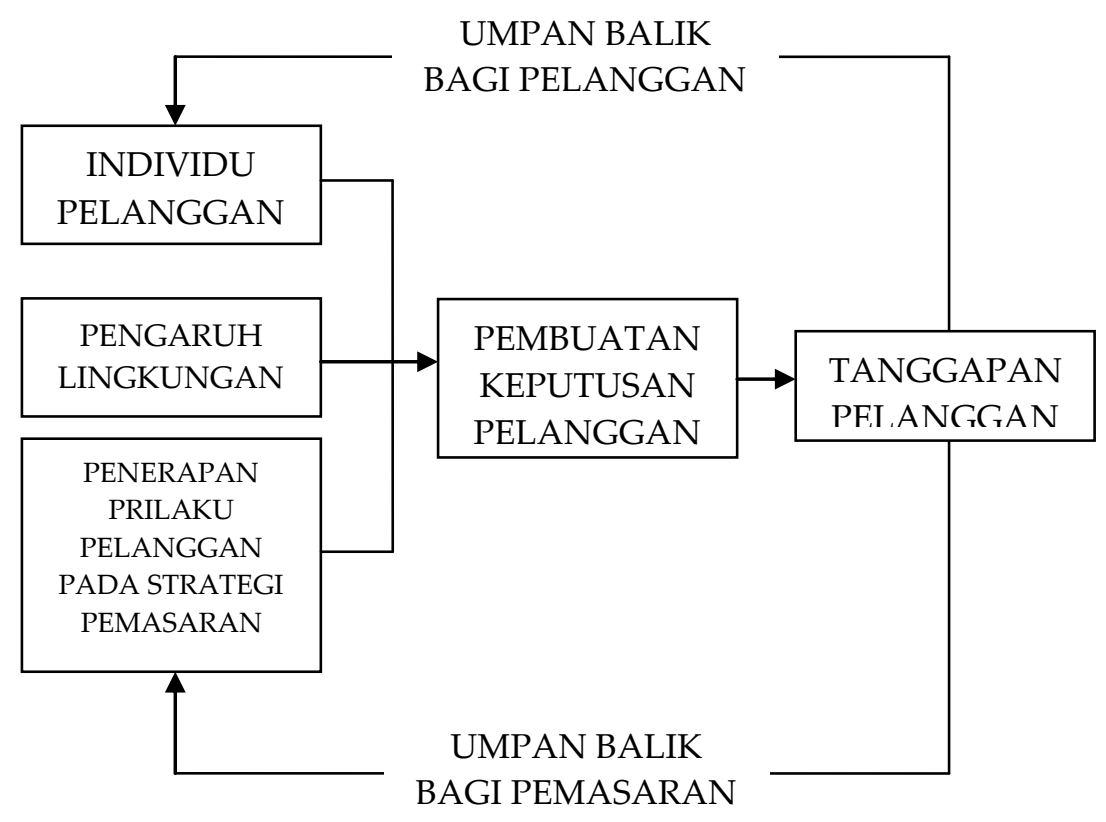

Gambar 1. Model Perilaku Pelanggan 
Apabila penyedia jasa dapat menyediakan kualitas layanan yang memenuhi kebutuhan semua segmen, maka diharapkan pelanggan akan loyal. Perkembangan ekonomi saat ini menunjukkan bahwa lebih banyak produk/jasa yang ditawarkan daripada permintaan. Kelebihan penawaran ini disebabkan beberapa hal, diantaranya karena kualitas produk/jasa kurang layak, spesifikasi produk/jasa tidak memenuhi keinginan/kebutuhan pelanggan atau pelanggan tidak mengetahui keberadaan produk tersebut.

Terdapat tiga faktor yang mempengaruhi pilihan pelanggan (Irawan, 2003), yaitu:

1. Individu pelanggan, artinya pilihan terhadap suatu produk dipengaruhi oleh hal-hal yang ada dalam diri pelanggan sendiri (kebutuhan, persepsi terhadap karakteristik merek, sikap, kondisi demografis, gaya hidup dan karakteristik kepribadian individu).

2. Lingkungan, yaitu bahwa keputusan membeli dipengaruhi oleh interaksi sosial yang telah dilakukan pelanggan.

3. Strategi pemasaran, sebagai salah satu faktor yang dapat dikendalikan oleh pemasar. Dalam hal ini, pemasar berusaha mempengaruhi pelanggan dengan menggunakan stimuli pemasaran, seperti iklan dan sejenisnya, supaya pelanggan bersedia memilih produk yang ditawarkan. Strategi pemasaran yang umum dikembangkan oleh pemasar yaitu berhubungan dengan produk yang ditawarkan, penentuan harga jual produk, strategi promosi dan bagaimana melakukan distribusi produk kepada pelanggan

\section{Segmentasi Pasar (Market Segmentation)}

Segmentasi pasar adalah proses membagi pasar keseluruhan suatu produk atau jasa yang bersifat heterogen ke dalam beberapa segmen, di mana masing-masing segmennya cenderung bersifat homogen dalam segala aspek (Irawan, 2003).
Pembagian segmen pasar:

1. Segmentasi pasar konsumen, yaitu membentuk segmen pasar dengan menggunakan ciri-ciri konsumen (consumer characteristic), kemudian organisasi akan menelaah apakah segmensegmen konsumen ini menunjukkan kebutuhan atau tanggapan produk yang berbeda.

2. Segmentasi pasar bisnis, yaitu membentuk segmen pasar dengan memperhatikan tanggapan konsumen (consumer responses) terhadap manfaat yang dicari, waktu penggunaan, dan merek.

Segmentasi pasar yang efektif menurut Tjiptono (2001):

1. Dapat diukur (measurable), ukuran, daya beli, profil segmen

2. Besar segmen (subtantial): cukup besar dan menguntungkan untuk dilayani

3. Dapat dijangkau (accessible): dapat dijangkau dan dilayani secara efektif

4. Dapat dibedakan (differentiable): secara konseptual dapat dipisahkan dan memberi tanggapan yang berbeda terhadap elemen dan program bauran;

5. Dapat diambil tindakan (actionable): program yang efektif dapat dirumuskan untuk menarik dan

melayani segmen tersebut.

Proses identifikasi pasar sasaran (target market) diawali dengan identifikasi segmen pasar yang akan dimasuki, yaitu memahami perilaku pelanggan. Segmentasi dapat dilakukan berdasarkan:

1. Geografis-demografis, yaitu populasi penduduk, lokasi, jaringan transportasi dan cuaca

2. Demografi individu, yaitu umur, jenis kelamin, pendidikan, mobilitas, pekerjaan, status perkawinan, ukuran rumah tangga, etnis, dan lain lain.

Menentukan pasar sasaran yang akan dimasuki, tergantung pada definisi pasar yang akan dikembangkan 


\section{Posisi Produk (Product Positioning)}

Ketika menentukan pasar sasaran sudah harus dipikirkan bagaimana memposisikan produk. Upaya memosisikan produk biasanya didasarkan pada tingkat harga, kualitas teknis, gaya hidup pelanggan dan sebagainya. Ketika produk tersebut diposisikan, pada saat yang sama harus dilihat pula kondisi/posisi produk pesaing.

\section{Persepsi Pelanggan}

Persepsi pelanggan berbeda dengan harapan pelanggan (customer expectation) karena harapan pelanggan bersifat dinamis, yang harus dievaluasi secara periodik setiap saat karena berbeda dari waktu ke waktu, berbeda untuk setiap orang dan setiap budaya. Kualitas layanan untuk harapan pelanggan sekarang berbeda untuk waktu yang akan datang. Layanan yang diterima pelanggan (customer perceived service) dapat diartikan sebagai kualitas layanan yang berkaitan dengan pengalaman pelanggan masing-masing (Zeithaml \& Mary, 2000).

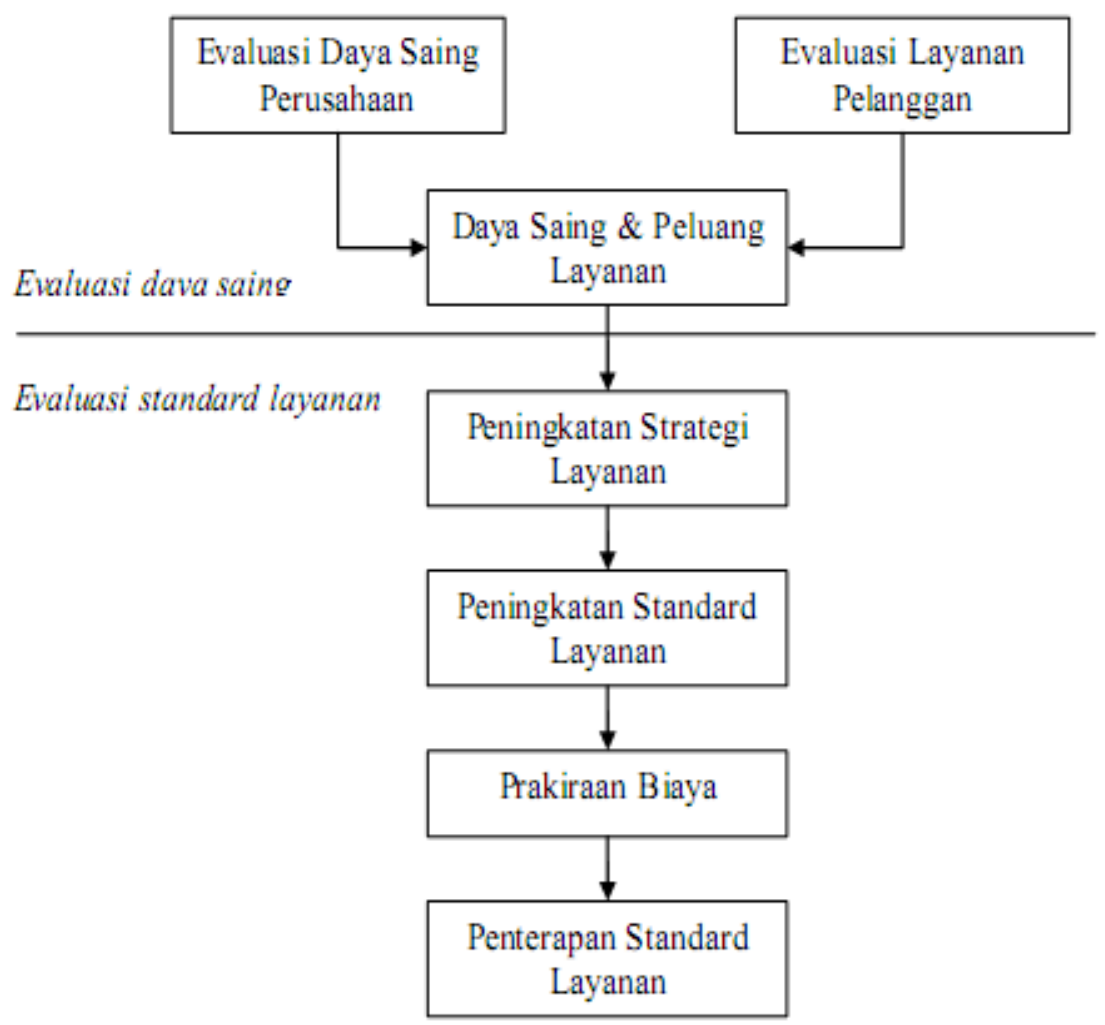

Gambar. 2 Kepuasan pelanggan dan daya saing perusahaan

\section{Posisi Kepuasan Pelanggan terhadap Daya Saing Perusahaan}

Hubungan antara kualitas layanan dengan daya saing perusahaan dijelaskan pada Gambar 2. Supaya perusahaan mempunyai daya saing dengan perusahaan sejenis (competitor), maka kepuasan pelanggan selalu dievaluasi terus menerus untuk mempertahankan standar tertentu yang dapat memenuhi keinginan pelanggan.
Kepuasan Pelanggan dan Kualitas Layanan Pengertian awam kepuasan pelanggan dan kualitas layanan adalah hal yang sama, tetapi sesungguhnya keduanya mempunyai arti yang berbeda. Kepuasan pelanggan mempunyai arti yang lebih luas, yang terdiri dari beberapa komponen yaitu kualitas layanan, kualitas produk, harga, faktor personal, dan faktor situasional (Zeithaml \& Mary, 2000). 


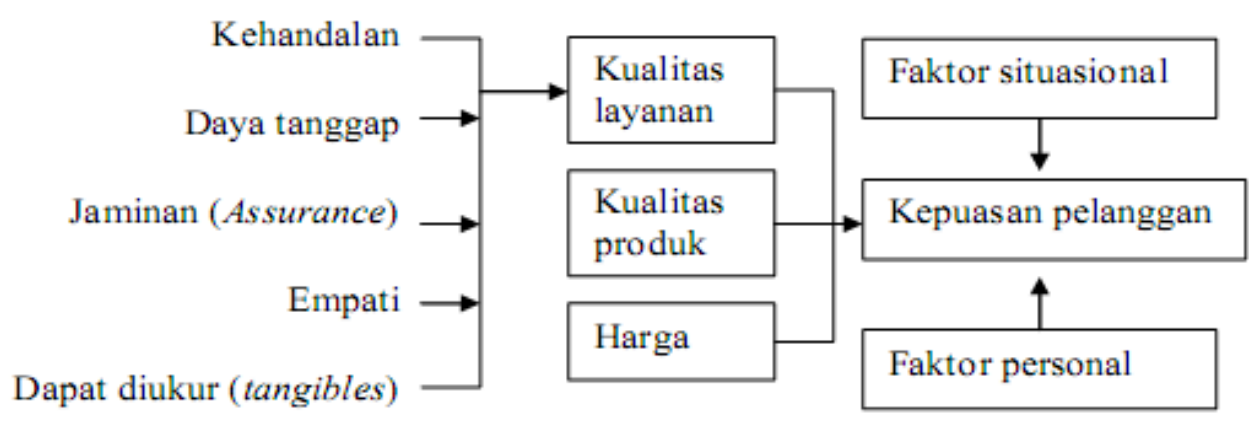

Gambar. 3 Posisi Kualitas Jasa terhadap Kepuasan Pelanggan

Kualitas layanan terdiri dari beberapa komponen yaitu kehandalan, daya tanggap, jaminan, empati dan dapat diukur. Sedangkan kepuasan pelanggan dipengaruhi oleh faktor kualitas layanan, kualitas produk, harga, faktor situasional dan faktor personal. Sebagai gambaran pada industri transportasi udara, faktor kualitas produk antara lain meliputi: jenis pesawat, kelas yang tersedia, fasilitas bandara; faktor harga yaitu harga tiket untuk bermacam segmen pelanggan, faktor personal yaitu pengalaman pelanggan dimasa lalu, harapan pelanggan, sedangkan faktor situasional adalah cuaca, keamanan pesawat, dan keselamatan penerbangan.

\section{Kepuasan Pelanggan dan Loyalitas}

Kepuasan dan loyalitas adalah sungguh memiliki korelasi yang erat dan memiliki hubungan yang misterius. Dari logika maupun pengalaman kita pribadi sebagai konsumen, kita tahu, kepuasan menghasilkan loyalitas, tetapi tidak 100\%. Dengan kata lain, tidak semua kepuasan menciptakan loyalitas. Di sisi lain, terdapat kebenaran juga bahwa walau konsumen tidak puas, tetap saja perusahaan dapat menciptakan loyalitas. Inilah salah satu tantangan bagi para pimpinan puncak dan marketer. Kita harus mampu menciptakan sumber-sumber kepuasan yang menghasilkan loyalitas. Keramahan dalam pelayanan atau fitur tertentu yang berhubungan dengan kualitas produk, sangatlah mungkin menjadi komoditas dan tidak menghasilkan loyalitas. Bia demikian, maka kita perlu mencari sumber kepuasan pada titik yang lebih tinggi sehingga menghasilkan loyalitas. Memuaskan pelanggan sehingga pelanggan benar-benar pada tingkat delighted, bisa jadi, terlalu mahal bagi perusahaan. Artinya, investasi dalam kepuasan pelanggan, tidak akan menghasilkan return yang memadai. Bila demikian, maka perusahaan haruslah mengkombinasikan strategi kepuasan pelanggan dan strategi loyalitas.

Strategi loyalitas cenderung membatasi setiap strategi yang menghasilkan loyalitas saja dan belum tentu memberikan kepuasan atau relatif tidak menaikkan tingkat kepuasan pelanggan secara nyata. Memberikan informasi yang cepat dan akurat adalah suatu strategi kepuasan yang menghasilkan loyalitas dalam dunia perbankan. Nasabah prioritas misalnya, akan merasa sangat puas kepada bank yang memberikan informasi mengenai produk-produk investasi yang tepat bagi kebutuhan dia. Apabila sebuah bank kemudian menawarkan produk reksadana yang tidak dapat ditarik selama 3 tahun atau memberikan penalti bila kemudian dicairkan, maka inilah strategi loyalitas. Pelanggan atau nasabah masuk dalam suatu strategi "locking". Dalam industri sepeda motor, maka kemudahan dan kecepatan dalam memperoleh kredit pembiayaan adalah strategi kepuasan pelanggan yang bisa menghasilkan loyalitas. Di sisi lain, besarnya waktu kredit dan bagaimana kontrak kredit diberlakukan agar membuat pelanggan tidak mudah pindah ke 
merek sepeda motor yang lain adalah murni sebagai strategi loyalitas. Demikian pula pada bidang kesehatan penyedia layanan harus mampu memberikan informasi serta kemudahan dan kecepatan dalam memberikan pelayanan yang dibutuhkan pasien.

\section{Indeks Kepuasan Pelanggan (Customer Satisfaction Index)}

Kepuasan pelanggan sangat penting untuk suatu perusahaan. Mengingat pelanggan yang puas akan kembali, membeli lagi dalam jumlah yang lebih besar, mereka menyebarkan pengalaman kepada teman yang ditemui, dan bersedia membayar lebih untuk berbisnis dengan pemasok/penyedia produk/jasa yang dipercaya. Dengan demikian upaya mempertahankan pelanggan dalam jangka pendek dapat meningkatkan revenue dan profit, sedangkan jangka panjang dapat membangun customer loyalty dan memperkuat brand. Statistik menunjukkan bahwa biaya untuk mempertahankan pelanggan lebih murah dari pada mencari pelanggan baru. Upaya untuk mempertahankan kepuasan pelanggan salah satunya adalah memantau apa yang mereka inginkan dari produk/jasa yang disajikan.

\section{Evolusi dan perkembangan Model Indeks Kepuasan Pelanggan Nasional}

Kepuasan pelanggan secara signifikan merupakan bagian dari Barometer Kepuasan Nasional dimulai dari Swedia (Fornell,1992), Amerika Serikat (Fornell, Johnson, Anderson, Cha, \& Bryant, 1996), dan Norwegia (Andreassen \& Lindestad, 1998). Indeks kepuasan pelanggan ini juga dikembangkan di New Zealand, Austria, Korea Selatan dan Uni Eropa, kemudian dikembangkan untuk tingkat ekonomi global. Validitas dan reliabilitas model dan metodologi indeks pengukuran kepuasan pelanggan dipelajari, diperbaiki dan dikembangkan secara terus menerus sepanjang waktu. Tulisan ini membahas model pengukuran tersebut dari sudut pandang ekonomi psikologi yang memposisikan customer loyalty sebagai variabel dependen. Untuk mengetahui posisi CSI Indonesia dibandingkan dengan negara penemu dan pemakai CSI lain maka perlu perbandingan dan kajian ilmiah. Perbandingan model pengukuran kepuasan pelanggan ini diawali dengan penjelasan model dan kerangka berpikir masing masing negara pemakai CSI. Pertimbangan yang mendasari pemilihan CSI dalam tulisan ini adalah Swedia sebagai negara penemu CSI, kemudian dikembangkan oleh Uni Eropa dan selanjutnya dipergunakan secara global. Amerika, sebagai negara adidaya yang menguasai ekonomi dunia sebagai bahan kajian berikutnya, Korea Selatan dan Jepang yang dapat dianggap sebagai salah satu negara Asia dengan perekonomian yang maju sehingga dapat dianggap mewakili kawasan Asia. Demikian pula Singaura dapat dianggap sebagai kekuatan ekonomi utama di kawasan Asia Tenggara. Tulisan ini membandingkan secara metodologis beberapa CSI yang dipergunakan oleh Swedia (SCSB), Amerika (ACSI), Eropa (ECSI),Korea Selatan (NCSI), Jepang (JCSI) Singapura (CSISG) dan Indonesia (ICSI). Pada umumnya kerangka berpikir untuk membangun CSI adalah sama, berawal dari Claes Fornell di Swedia dengan SCSB.

\section{PEMBAHASAN}

\section{Perbandingan Indeks Kepuasan Pelanggan (CSI) masing masing negara SCSB}

Konsep pengukuran kepuasan pelanggan dengan sekala nasional pertama kali dilakulan di Swedia pada 1989 dengan nama Swedish Customer Satisfaction Barometer. SCSB dikembangkan oleh Claes Fornell, warga negara Swedia yang mendapatkan Ph.Dnya dari University of Lund, Swedia. 
Selain sebagai pakar kepuasan pelanggan, Fornell juga penerima beasiswa Fulbright di University of California at Berkeley dan juga profesor di Ross Michigan Business School, serta pendiri lembaga konsultan Claes Fornell International. Model ini menjelaskan pengukuran kepuasan pelanggan yang dilakukan untuk customer loyalty yaitu pengalaman pelanggan membeli jasa dan produk selama periode waktu tertentu. Model ini diterapkan untuk sektor industri transportasi dan telekomunikasi. Swedish Customer Satisfaction Barometer (SCSB) sendiri melibatkan 130 perusahaan dari 32 sektor .

\section{ACSI}

Sukses di Swedia, selanjutnya pada 1994 Fornell pun mengadopsi konsep yang sama untuk AS yang dinamakan American Customer Satisfaction Index (ACSI), yang dibangun oleh Claes Fornell International bermitra dengan Ross Michigan Business School dan American Society of Quality.

ACSI mewawancarai 80.000 warga AS setiap tahun untuk mengetahui kepuasan mereka terhadap produk dan jasa ataupun layanan pemerintahan. Perusahaan yang disurvei mencapai 200 perusahaan dengan 43 industri dan 10 sektor ekonomi. Pengukuran dilakukan setiap tiga bulan dan industri yang diliput di-rolling. ACSI memakai dua metode yang saling melengkapi: wawancara pelanggan dan pemodelan ekonomi. Dengan memakai teknologi Computer asssited telephone interviewing, pewawancara menelepon pelanggan yang telah dipilih dan disaring secara acak. Telepon secara acak tersebut dilakukan dengan memakai metode sampling random-digit sehingga menjamin perwakilan populasi pelanggan Amerika. Model ACSI sendiri adalah model sebab-akibat dengan indeks pemicu kepuasan konsumen di sisi kiri (customer expectations, perceived quality and perceived value), kepuasan (ACSI) di tengah, dan keluaran di sisi kanan (customer complaints dan customer loyalty, termasuk customer retention dan price tolerance).

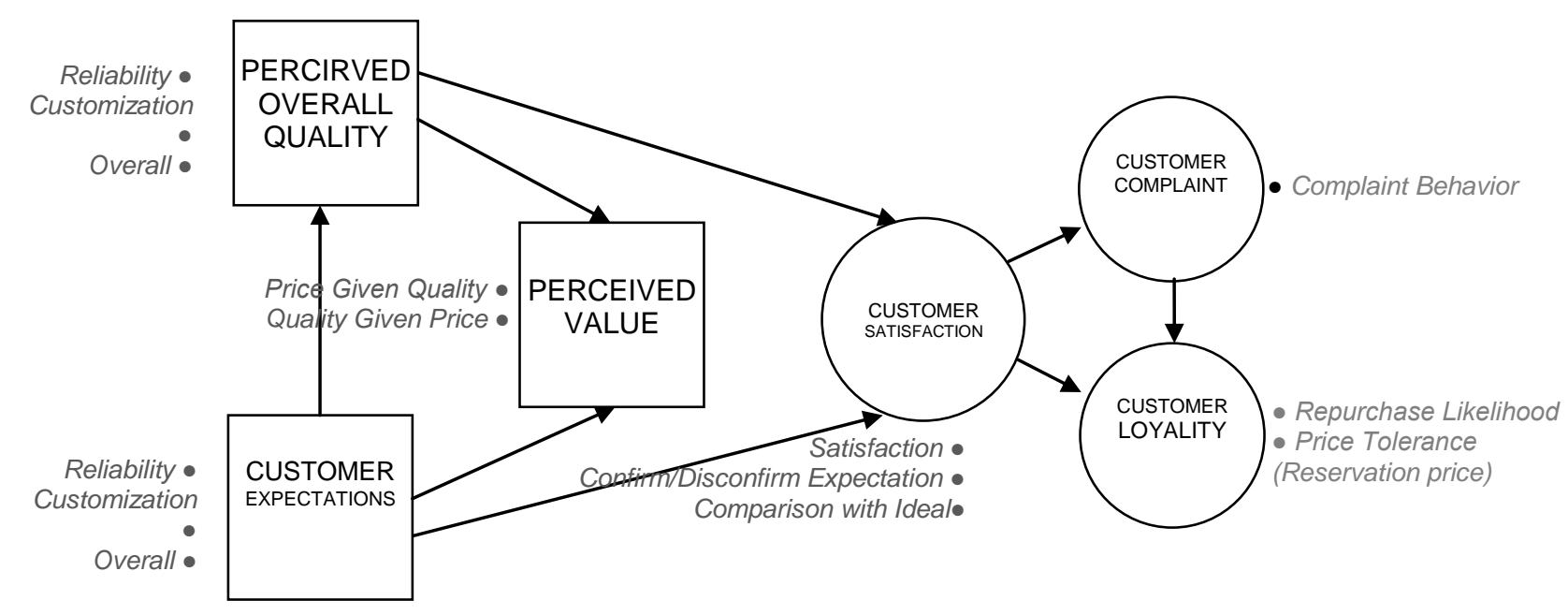

Gambar 4 Model American Customer Satisfaction Index (ACSI) 
Indeks tersebut adalah komponen multivariate yang diukur dari pertanyaan yang kemudian dibobotkan ke dalam model tersebut. Metodologi modeling dan survei menghitung kekuatan efek indeks di sisi kiri terhadap komponen yang ditunjuk oleh panah di sisi kanan. Dengan melihat indeks dan dampak, pengguna akan dapat menentukan pemicu kepuasan pelanggan yang, bila ditingkatkan, akan memberikan dampak positif terhadap loyalitas pelanggan. Pertanyaan mengenai kepuasan pelanggan yang diajukan terdiri atas tiga kerangka: kepuasan keseluruhan (overall satisfaction), pemenuhan harapan (expectancy) dan kinerja (performance). Hasil akhirnya, semua perusahaan akan mendapatkan skor ACSI, yang juga merupakan indeks kepuasan pelanggan, dengan rentang 0 sampai 100 . Walaupun survei tersebut lintas-industri, sehingga ada sedikit perbedaan pertanyaan, pertanyaan yang diajukan pada dasarnya identik. Dengan demikian, metode ini mampu memberikan perbandingan antarperusahaan maupun antar-industri. Karena metodologinya yang sangat kuat, ACSI juga dipakai sebagai acuan oleh akademisi, perusahaan, pemerintah, analis saham dan konsumen. ACSI dapat pula menghasilkan indeks kepuasan konsumen nasional, yang merupakan gambaran tingkat kepuasan konsumen Amerika secara rata-rata. Indeks ini dihasilkan dari rata-rata berbobot kepuasan industri. Indeks nasional ini juga memungkinkan periset melihat korelasi antara kepuasan konsumen dan makroekonomi.

Hasil penelitian lebih lanjut membuktikan, ada hubungan erat antara nilai ACSI nasional dan data ekonomi makro. Fornell menemukan bahwa indeks ACSI dapat dipakai sebagai acuan untuk memperkirakan Produk Domestik Bruto dan Personal Consumption Expenditure.

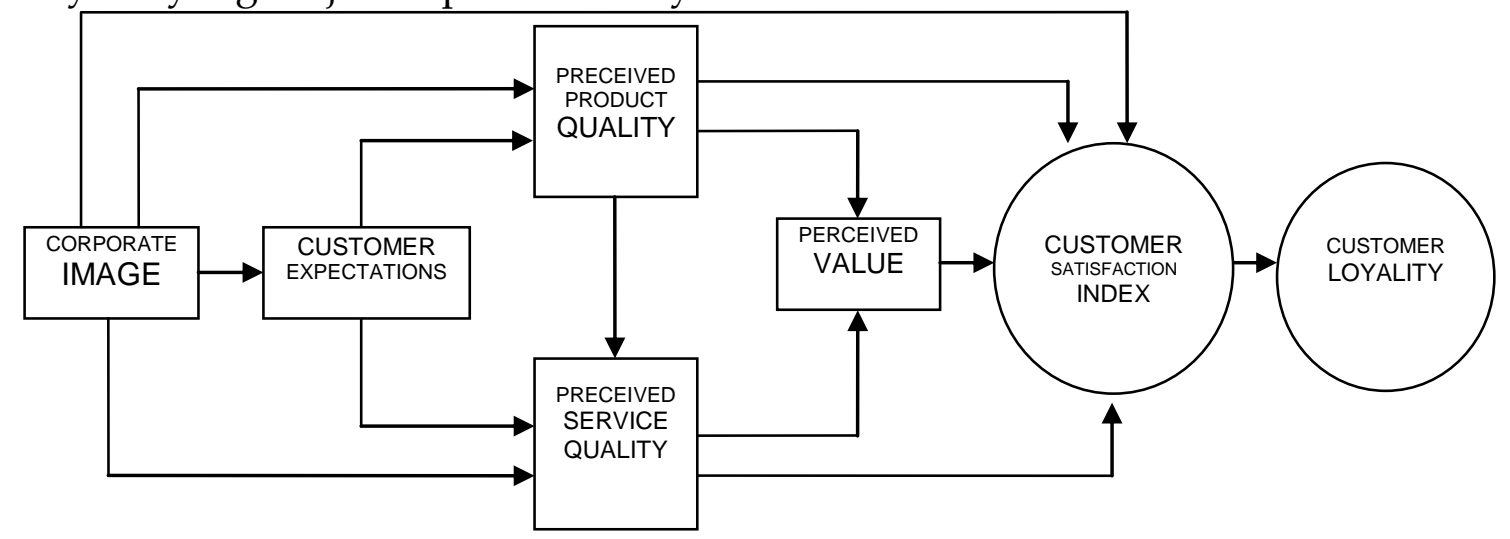

Gambar 5 Model European Customer Satisfaction Index (ECSI)

\section{ECSI}

Eropa juga memiliki model pengukuran kepuasannya yang dinamai European Customer Satisfaction Index (ECSI). Metode yang dipakai juga sama dengan model yang dipakai di Swedia, artinya juga sama dengan model di AS. ECSI mencakup lintas negara di Eropa, bukan dibatasi negara lagi, dengan sekretariat riset di Stokholm, Swedia. Pilot project untuk Eropa diluncurkan pada 1999 dengan 100.000 wawancara di 12 negara. 
Industri yang dilingkup mencapai 10 industri di beberapa negara dan empat industri di hampir semua negara (perbankan ritel, telekomunikasi, ponsel dan supermarket).

\section{NCSI}

Model pengukuran kepuasan konsumen Korea Selatan disebut sebagai National Customer Satisfaction Index (NCSI). Survei tersebut melibatkan sekitar 60.000 responden dengan metode melalui telepon dan one-on-one. Industri yang diliput mencapai 37 industri dan 200 perusahaan. Metode yang dipakai sama dengan metode yang dipakai di Swedia maupun AS. Model ini juga menghubungkan kepuasan konsumen (NCSI) dengan perilaku konsumen yang terdiri dari komplain konsumen dan loyalitas konsumen. Loyalitas konsumen yang dimaksud dapat berupa kemungkinan pembelian ulang atau toleransi harga.

\section{CSISG}

Pada 7 April 2008, Singapura secara resmi mengumumkan peluncuran Customer Satisfaction Index of Singapura (CSISG). Inisiatif tersebut diluncurkan di Institute of Service Excellence, Singapore Management University, dengan menghadirkan Claes Fornell sebagai pembicara utama. Nilai kepuasan nasional Singapura adalah 68,7 (dari skala 100), lebih rendah dari Korsel dengan nilai 72 dan AS dengan nilai 75 . Wawancara yang dipakai mencapai sekitar 10.000 rumah tangga dan 2.000 turis untuk sektor yang relevan. Turis yang paling banyak disurvei adalah dari Indonesia dan kemudian Cina, Australia, Malaysia dan India. Hasil yang mengejutkan adalah bahwa para turis memberikan nilai kepuasan yang sekitar 10 poin lebih tinggi daripada warga Singapura. Mengingat Singapura terdiri atas beraneka ragam ras, bahasa yang dipakai adalah Inggris, Melayu dan Cina. Sementara metode di AS melalui telepon, di Singapura secara face-to-face. Karena diadopsi dari model ACSI, pertanyaan yang diajukan juga mendekati pertanyaan ACSI, yaitu mengenai kepuasan keseluruhan, pemenuhan harapan, serta perbandingan antara kinerja dan ideal.

\section{JCSI}

The Service Productivity \& Innovation for Growth (SPRING) Jepang mengembangkan Japanese Customer Satisfaction Index (JCSI) yang didukung Kementerian Ekonomi, Perdagangan dan Industri dengan cakupan 150 perusahaan dari 18 sektor. Model pengukuran JCSI dikembangkan oleh akademisi bersama company advisory group sehingga kebutuhan perusahaan dapat diakomodasi dalam model yang dikembangkan. Hampir semua universitas terkemuka di Jepang dilibatkan, misalnya Waseda University, Hitotsubashi University, Keio University dan Kobe University. Perusahaan yang terlbat juga sangat banyak dan umumnya perusahaan besar, antara lain All Nippon Airways, Japan Airways, NTT DoCoMo, Aeon, peritel iSetan dan 7-Eleven. Model yang dikembangkan tidak jauh berbeda dari model Swedia. Hanya saja, model Jepang ini mulai memakai responden dari Internet. Selain itu, model Jepang ini juga mengukur word of mouth dan loyalitas. 


\section{ICSI}

Pada saat ini, di Indonesia telah terdapat indeks pengukuran berskala nasional yang dilakukan oleh Frontier Marketing \& Research Consultant, yang dikenal dengan nama Indonesian Customer Satisfaction Index (ICSI), dimana hasil-hasilnya telah menjadi tolok ukur bagi para pemilik merek di Indonesia untuk melihat kinerjanya dalam memberi kepuasan kepada pelanggan dibandingkan dengan merek pesaing. Selain itu, pengukuran indeks kepuasan secara nasional ini berguna bagi perusahaan terutama memberikan informasi mengenai rata-rata indeks kepuasan industri, yang tidak mungkin dilakukan sendiri oleh suatu perusahaan mengingat biaya yang diperlukan cukup besar.

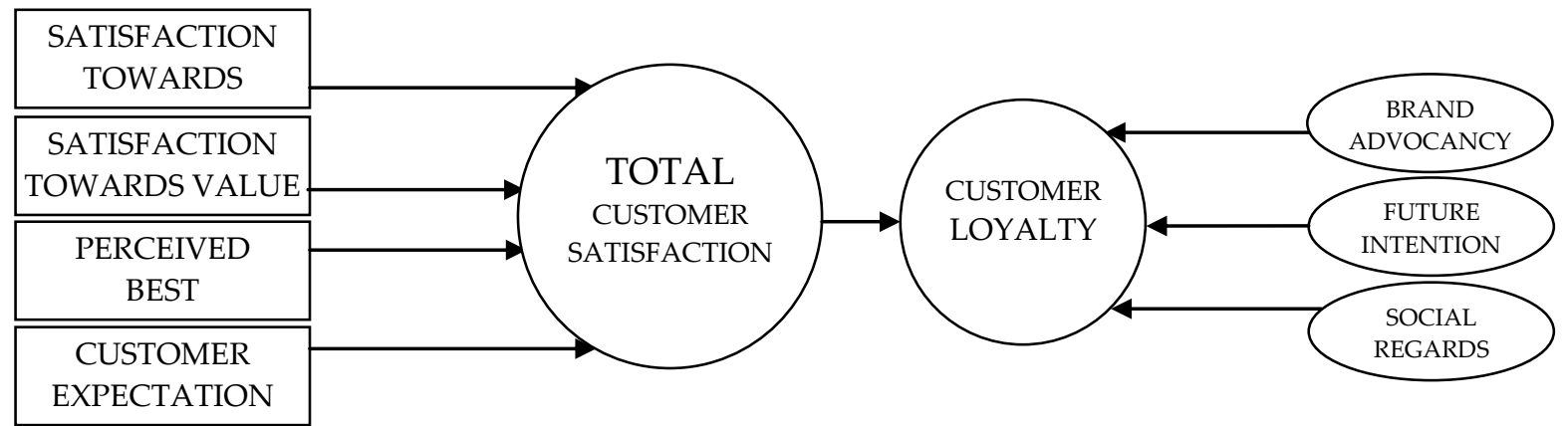

Gambar Model Indonesian Customer Satisfaction Index (ICSI)

Dalam survei ICSI ini, 4 hal yang dijadikan ukuran kepuasan pelanggan, yaitu: kepuasan terhadap kualitas produk atau kualitas pelayanan (Quality Satisfaction Score/QSS)TM, kepuasan terhadap harga berdasarkan kualitas yang diterima (Value Satisfaction Score/VSS), dan persepsi bahwa merek yang dipergunakan secara keseluruhan merupakan merek yang paling baik dibandingkan dengan merek-merek lainnya (Perceived Best Score/PBS) serta harapan konsumen terhadap produk atau layanan (Customer Expectation). Keempat hal tersebut dijadikan ukuran atas dasar asumsi : "Pelanggan akan puas jika merek yang digunakan berkualitas, pelanggan akan puas jika harga dari merek yang digunakan sesuai dengan kualitas yang diterima, dan pelanggan akan puas jika pelanggan sudah merasa bahwa merek yang dipergunakan adalah paling baik dibandingkan merek lainnya". Terhadap ke-4 variabel tersebut kemudian dilakukan analisa regresi dengan tingkat loyalitas sehingga menghasilkan (TSS/Total Satisfaction Score) TM, yang menjadi ukuran peringkat dalam ICSI.

\section{Pemetaan CSI}

Hasil kajian secara metodologis adalah pemetaan Customer Satisfaction Index untuk negara: Swedia, Amerika, Uni Eropa, Korea Selatan, Jepang, Singapura dan Indonesia yang disajikan pada Tabel 1 dan Tabel 2. 
Tabel . Kajian Metodologis Customer Satisfaction Index yang ditinjau

\begin{tabular}{|l|c|c|c|c|c|c|c|}
\hline & SCSB & ACSI & ECSI & NCSI & JKCSI & CSISG & ICSI \\
\hline Hubungan konsumen & & & & $\sqrt{ }$ & & & \\
\hline Pandangan suplier & & & $\sqrt{ }$ & & & & \\
\hline Nilai yang tampak & $\sqrt{ }$ & $\sqrt{ }$ & & & $\sqrt{ }$ & $\sqrt{ }$ & $\sqrt{ }$ \\
\hline $\begin{array}{l}\text { Persepsi konsumen terhadap } \\
\text { kualitas layanan }\end{array}$ & $\sqrt{ }$ & $\sqrt{ }$ & $\sqrt{ }$ & $\sqrt{ }$ & $\sqrt{ }$ & $\sqrt{ }$ & $\sqrt{ }$ \\
\hline $\begin{array}{l}\text { Persepsi konsumen terhadap } \\
\text { kualitas produk }\end{array}$ & $\sqrt{ }$ & $\sqrt{ }$ & $\sqrt{ }$ & $\sqrt{ }$ & $\sqrt{ }$ & $\sqrt{ }$ & $\sqrt{ }$ \\
\hline Kompalin konsumen & $\sqrt{ }$ & $\sqrt{ }$ & & $\sqrt{ }$ & & $\sqrt{ }$ & \\
\hline Loyalitas konsumen & $\sqrt{ }$ & $\sqrt{ }$ & $\sqrt{ }$ & $\sqrt{ }$ & $\sqrt{ }$ & $\sqrt{ }$ & $\sqrt{ }$ \\
\hline Harapan konsumen & $\sqrt{ }$ & $\sqrt{ }$ & $\sqrt{ }$ & & $\sqrt{ }$ & $\sqrt{ }$ & $\sqrt{ }$ \\
\hline Word of Mouth & & & & & $\sqrt{ }$ & & \\
\hline
\end{tabular}

\section{PENUTUP}

Dari semua CSI yang ditinjau pengukuran sampel bersifat acak, tidak ada pembobotan kriteria yang prioritas menurut pelanggan. Kriteria yang dipilih berguna untuk menunjang perbaikan kinerja proses peningkatan kualitas layanan kepada pelanggan. Sehingga dapat disimpulkan bahwa dasar pembentukan index adalah ratarata tertimbang (weighted arithmatic mean).

Apabila tinjauan berbasis customer loyalty sebagai variabel dependen maka keluhan pelanggan dan pengalaman yang lalu menjadi isu pokok dalam Indonesian Customer Satisfaction Index (ICSI) tersebut. Sebagai bahan perbandingan untuk perbaikan sebaiknya ICSI:

a. Mengembangakan pengukuran kepuasan konsumen khususnya bagi bidang pelayanan kesehatan

b. Mengukur indeks berbasis tinjauan proses jasa dan produksi,

c. Mempertimbangkan keluhan pelanggan, dan word of mouth

d. Aspek perceived quality, perceived value, customer expectation, seluruh aspek customer loyalty, customer Satisfaction dan customer complain juga diukur dan diperhitungkan

\section{REFERENSI}

Akbari, M.,Naderi, M., Razizadeh, H.,Ebrahiminiah, K., \& Roohipour, M. (2013), Model Of Customer Satisfaction And Comparison of Different Models, International Journal of Business and Behavioral Sciences 3 (5), 68-76

Anderson, E.W., Fornel, C. \& Lehman, D.R .(1994). Customer satisfaction, market share and profitability. Journal of Marketing 58 (3), 53-66.

Andreassen, T.W. \& Lindestad, B. (1998). Customer loyalty and complex services: The significance of quality, image and satisfaction on customer loyalty. International Journal of Service Industry Management, 9 (1).

Angelova, B., Zekiri, J., (2011), Measuring Customer Satisfaction with Service Quality Using American Customer Satisfaction Model (ACSI Model), International Journal of Academic Research in Business and Social Sciences October 2011, 1 (3), 232-258

Can, L.K., Hui, Y.V., Lo, H.P., \& Tze, S.K. (2003). Customer satisfaction index: New practice and findings. Europen Journal of Marketing, 22, 872-909.

Direktorat Niaga PT Garuda Indonesia. (2002)\

Fornel, C. (1992). A national customer 
satisfaction barometer: The Swedish experience. Journal of Marketing 56 (1).

Fornel, C., Johnson, M.D., Anderson, E.W, Cha, J., \& Bryant, B.E. (1996). The American Satisfaction Index: Nature, purpose and finding. Journal of Marketing, October; 60;4 ABI/INFORM, Global, p. 7.

Fornel, C. \& Wernelfeld, B. (1987). Defensive marketing strategy by customer complaint management: A theoretical analysis. Journal of Marketing Research, 24.

Grigoroudis, E. \& Siskos, Y. (2004). A survey of customer satisfaction barometers: Some results from transportationcommunication sector. European Journal of Operation Research 152, 334353.

Irawan, H.D. (2003). Indonesian Customer Satisfaction: Membedah strategi kepuasan pelanggan merek pemenang ICSA. Elex Media Computindo.

Reichelt, F.F. \& Sasser, W.E (1990). Zero defections: Quality comes to services. Harvard Business Review, 68 (5).

Schiffman, L.G. \& Leslie, K.K. (2000). Consumer behaviour. New Jersey: Prentice Hall Inc. Tjiptono, F. (2001). Strategi pemasaran. Yogyakarta: Andi Offset

Zeithaml, V.A. \& Mary J.B. (2000). Service marketing, integrating customer focus across the firm. Irwin Mc Graw Hill. 